\title{
Mechanical Property Improvement for Aluminum Alloy Al-7Si with Additive Material of Al-TiB and Heat Treatment of T5
}

\author{
Suhariyanto, Syamsul Hadi, Hari Subiyanto, Mahirul Mursid, and Gatot Dwi W.
}

\begin{abstract}
Aluminum alloy Al-7Si is suitable for material of wheel rim of racing car, however its mechanical properties has not met the required standard JIS H5202, so it needs to be improved. Improving mechanical properties can be done by adding element alloys and heat treatment. This present research in concerning with Al-TiB enhancement into the Al-7Si aluminum alloy to increase the Titanium content of $0.13 \% \mathrm{w}$ to $0.14 \% w, 0.15 \% w, 0.16 \% w$ until $0.21 \%$. Therefore, these samples were treated by heat treatment T5. The Addition of Al$T i B$ caused the micro structure of the grain become smaller and softer, and also increases the mechanical properties (UTS and Hardness), but it has not met standard JIS H5202 yet. After heat treatment T5, the form of grain change from ellipse to circular, the mechanical properties improve significantly and beyond the standard JIS H5202.
\end{abstract}

Keywords-Al-7Si, AlTiB, mechanical properties, $T 5$.

\section{INTRODUCTION}

Al-7Si Alloy is one of aluminum alloy which is suitable for racing car because it has lightweight, corrosion resistant and attractive color, but its mechanical properties still need to be improved. Mechanical properties required for the material racing car, in accordance with JIS H 5202 Standard, namely: UTS (Ultimate Tensile Strenght) at least $25 \mathrm{~kg} / \mathrm{mm}^{2}$ or $245,25 \mathrm{Mpa}$, Elongation minimum 5\%, hardness $75 \mathrm{~s} / \mathrm{d} 95 \mathrm{Hv}$ and Impact Strength (IS) minimum $5.90 \mathrm{~J} / \mathrm{cm}^{2}$. Whereas Al-7Si aluminum alloy has UTS $16,36 \mathrm{~kg} / \mathrm{mm}^{2}$ or $160,49 \mathrm{Mpa}$, hardness $54,25 \mathrm{Hv}$ and IS $7,34 \mathrm{~J} / \mathrm{cm}^{2}$. So it is necessary to do research that aims to improve the mechanical properties of these alloys. The research that will be done is to add Titanium (Ti) in the form of $\mathrm{Al}-\mathrm{TiB}$ master alloy or often abbreviated $\mathrm{TiB}$ (Titanium Boron) into $\mathrm{Al}-7 \mathrm{Si}$ alloy, then continued with heat treatment ( $\mathrm{T} 5$ heat treatment).

\section{LITERATURE STUDY}

\section{A. Grain Refiner on Aluminum Alloys}

Al-TiB alloys and Al-TiC alloys can be used to smooth aluminum granules. This is because $\mathrm{TiB}$ or $\mathrm{TiC}$ which has a diameter of about 1 micron added to the aluminum fluid can be the core of the aluminum grain. Al-TiB Alloy is a grain refiner for aluminum fluid that can cause core particles, so

Suhariyanto, Syamsul Hadi, Hari Subiyanto, Mahirul Mursid, and Gatot Dwi Ware with Department of Industrial Mechanical Engineering, Institut Teknologi Sepuluh Nopember, Surabaya, 60111, Indonesia. Email: atriapradityana@gmail.com. it can produce fine grains and prevent the formation of columnar granules on cast products. The types of TiB alloys and the chemical composition ratio of Titanium and Boron can be seen in the Table 1 .

TABLE 1.

TYPES OF TIB ALLOYS AND COMPARISON OF CHEMICAL COMPOSITION [1]

\begin{tabular}{|c|c|c|c|c|c|}
\hline No & Alloy & $\begin{array}{c}\text { European } \\
\text { Standard } \\
\text { EN575:199 } \\
\text { 5Reg. No. }\end{array}$ & $\begin{array}{l}\text { Compositi } \\
\text { on Limits } \\
\text { Maximum } \\
\text { unless } \\
\text { shown as a } \\
\text { range }\end{array}$ & $\begin{array}{l}\text { Colour } \\
\text { Coding }\end{array}$ & Form \\
\hline 1 & Ti3B1 & 92250 & $\begin{array}{l}\text { Ti } 2.7-3.5 \\
\text { Si } 0.30 \\
\text { Others } \\
0.04 \\
\text { Bi } 0.8- \\
1.20 \mathrm{Fe} \\
0.30 \\
\text { Total } \\
0.10 \\
\text { V } 0.20\end{array}$ & $\begin{array}{l}\text { Green, } \\
\text { Red }\end{array}$ & $\begin{array}{l}\text { Waffle } \\
\text { Rod } \\
\text { Cut } \\
\text { Cast } \\
\text { Bar } \\
\text { Sticks }\end{array}$ \\
\hline 2 & Ti5B0.2 & 92252 & $\begin{array}{l}\mathrm{Ti} 4.5-5.5 \\
\mathrm{Si} 0.30 \\
\text { Others } \\
0.04 \\
\mathrm{Bi} 0.15- \\
0.25 \mathrm{Fe} \\
0.30 \text { Total } \\
0.10 \\
\mathrm{~V} 0.25\end{array}$ & $\begin{array}{c}\text { Green, } \\
\text { Black }\end{array}$ & $\begin{array}{l}\text { Waffle } \\
\text { Rod } \\
\text { Cut } \\
\text { Cast } \\
\text { Bar } \\
\text { Sticks }\end{array}$ \\
\hline 3 & Ti5B0.6 & 92254 & $\begin{array}{l}\mathrm{Ti} 2.7-3.5 \\
\mathrm{Si} 0.30 \\
\text { Others } \\
0.04 \\
\mathrm{Bi} 0.50- \\
0.80 \mathrm{Fe} \\
0.30 \text { Total } \\
0.10 \\
\mathrm{~V} 0.20\end{array}$ & $\begin{array}{l}\text { Green, } \\
\text { Yellow }\end{array}$ & $\begin{array}{l}\text { Waffle } \\
\text { Rod } \\
\text { Cut } \\
\text { Cast } \\
\text { Bar }\end{array}$ \\
\hline 4 & Ti5B1 & 92256 & $\begin{array}{l}\mathrm{Ti} 2.7-3.5 \\
\mathrm{Si} 0.30 \\
\text { Others } \\
0.04 \\
\mathrm{Bi} 0.9-1.1 \\
\mathrm{Fe} 0.30 \\
\text { Total } \\
0.10 \\
\mathrm{~V} 0.20\end{array}$ & Green & $\begin{array}{l}\text { Waffle } \\
\text { Rod } \\
\text { Cut } \\
\text { Cast } \\
\text { Bar } \\
\text { Sticks }\end{array}$ \\
\hline
\end{tabular}

In addition to $\mathrm{Al}-\mathrm{TiB}$ which is also often used as a granular smolder on aluminum alloys are $\mathrm{Al}-\mathrm{TiC}$, and $\mathrm{Al}$ TiC is often used Ti3C0.15 which has the chemical composition as follows: $\mathrm{Ti}=3 ; \mathrm{Si}=0.30 ; \mathrm{Fe}=0.35 ; \mathrm{C}=$ 
$0.15 ; \mathrm{B}=0.004$; each others 0.03 the rest is Aluminum [1]. The following is the result of research on the influence of the addition of Al-TiC to the mechanical properties (without heat treatment).

TABLE 2.

EFFECT OF AL-TIC ADDITION ON MECHANICAL PROPERTIES [2]

\begin{tabular}{|c|c|c|c|c|c|}
\hline No & Ti (\%w) & $\begin{array}{c}\mathrm{UTS} \\
\left(\mathrm{kg} / \mathbf{m m}^{2}\right)\end{array}$ & $\varepsilon(\%)$ & HVN & IS $\left(\mathbf{J} / \mathbf{c m}^{2}\right)$ \\
\hline 1 & 0,13 & 16,36 & 10,23 & 54,25 & 6,34 \\
\hline 2 & 0,15 & 20,18 & 9,43 & 62,32 & 6,24 \\
\hline 3 & 0,17 & 22,47 & 8,37 & 70,52 & 6,12 \\
\hline 4 & 0,19 & 23,24 & 8,21 & 74,28 & 5,97 \\
\hline 5 & 0,21 & 22,56 & 7,89 & 73,96 & 5,94 \\
\hline
\end{tabular}

Based on the results of this study, it can be concluded that: the addition of Al-TiC can improve the quality of Al-
7Si material, but still cannot meet JIS H5202 standard, so it needs to be continued with heat treatment (Table 2).

\section{B. Heat Treatment}

Thermal treatment can be defined as a combination of heating and cooling operations against metal / alloys in solid state for a certain time and with a view to obtaining certain properties.

Some research related to this is: $\mathrm{Al} \mathrm{Al}$ can be upgraded its hardness by way of heat treatment, for example Al-Si-Mg aluminum alloy is given T5 heat treatment (4 hours hold time with varying temperature: $25 ; 125 ; 180 ; 200$ and 220 oC) [3]. The results showed that: initially its hardness was $92 \mathrm{BHN}$, at $180 \mathrm{oC}$ heating temperature, hardness became $117 \mathrm{BHN}$ and at heating temperature $200 \mathrm{oC}$, hardness became $226 \mathrm{BHN}$.

TABLE 2.

THE RESULT OF TESTING OF MECHANICAL PROPERTIES, TI INFLUENCE AND T5 HEAT TREATMENT ON MECHANICAL PROPERTIES

\begin{tabular}{|c|c|c|c|c|c|c|c|c|c|}
\hline \multirow[t]{2}{*}{ No } & \multirow[t]{2}{*}{ Ti (\%w) } & \multicolumn{2}{|c|}{ UTS $\left(\mathrm{kg} / \mathrm{mm}^{2}\right)$} & \multicolumn{3}{|c|}{$\varepsilon(\%)$} & \multicolumn{2}{|c|}{ HVN } & \multirow{2}{*}{$\begin{array}{r}\text { IS }\left(\mathrm{J} / \mathrm{cm}^{2}\right) \\
\mathrm{T5}\end{array}$} \\
\hline & & Cast & T5 & Cast & T5 & Cast & T5 & cast & \\
\hline 1 & 0,13 & 16,36 & 25,14 & 10,23 & 8,72 & 54,25 & 80,27 & 6,34 & 6,07 \\
\hline 2 & 0,14 & 18,34 & 27,56 & 9,53 & 8,34 & 58,32 & 83,74 & 6,24 & 6,02 \\
\hline 3 & 0,15 & 20,12 & 29,46 & 9,36 & 8,12 & 62,33 & 86,46 & 6,21 & 5,97 \\
\hline 4 & 0,16 & 21,68 & 30,58 & 9,53 & 8,04 & 66,32 & 88,74 & 6,22 & 5,95 \\
\hline 5 & 0,17 & 22,25 & 32,38 & 8,33 & 7,98 & 70,44 & 89,24 & 6,23 & 5,94 \\
\hline 6 & 0,18 & 22,28 & 33,58 & 8,27 & 8,14 & 74,32 & 93,74 & 6,28 & 5,92 \\
\hline 7 & 0,19 & 22,23 & 32,83 & 8,21 & 7,12 & 73,26 & 92,16 & 5,96 & 5,88 \\
\hline 8 & 0,20 & 22,18 & 31,58 & 8,43 & 7,54 & 71,32 & 90,74 & 5,24 & 5,86 \\
\hline 9 & 0,21 & 21,85 & 31,45 & 8,78 & 7,67 & 70,63 & 90,46 & 5,12 & 5,82 \\
\hline 10 & 0,22 & 21,26 & 30,41 & 8,89 & 7,97 & 69,96 & 89,42 & 5,04 & 5,82 \\
\hline
\end{tabular}

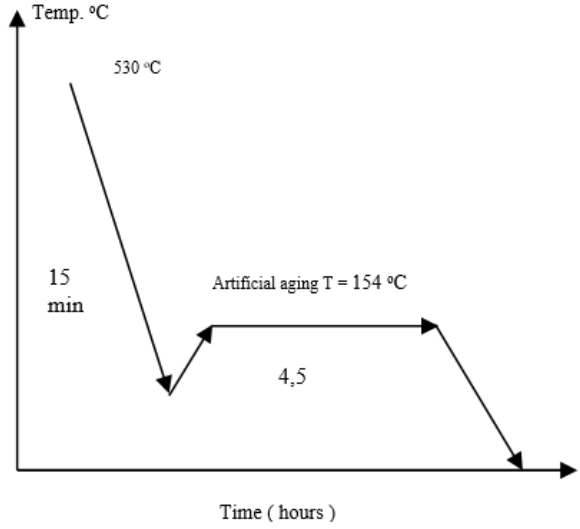

Figure 1. Schematic of T5 heat treatment process.

Other studies have shown that to improve the hardness of $\mathrm{Al}-\mathrm{Si}-\mathrm{Mg}$ alloys can also with $\mathrm{T} 6$ heat treatment as has been done to aluminum alloys with AC9B series number for piston material [Elvis S, 1997]. The results show that the highest hardness that can be achieved is $75 \mathrm{HRB}$, when given T6 heat treatment with $200 \mathrm{oC}$ temperature with 4 hours hold time. As-cast aluminum is susceptible to dimensional changes, decreased strength, toughness, and corrosion resistance. To overcome this as well as to increase strength and ductility, the casting result needs to be processed thermally (heat tretment) with one or more heating followed by cooling [4].
T5 heat treatment is used, because the time required is shorter and the cost is cheaper than T6.

In the $\mathrm{T} 5$ heat treatment there is no need for dissolved heating to a temperature of about $530^{\circ} \mathrm{C}$ and holding time of $6 \mathrm{~h}$, as performed by T6. For T5 heat treatment, direct Velg-racing from cast results, the temperature is awaited until about $530{ }^{\circ} \mathrm{C}$. After the temperature reaches $530{ }^{\circ} \mathrm{C}$ new quenching done to $70{ }^{\circ} \mathrm{C}$ in 15 minutes, complete can be seen in Figure 1.

\section{METHODOLOGY}

The chemical composition (\% w) of $\mathrm{Al}-7 \mathrm{Si}$ alloys are: $\mathrm{Al}$ $=92.48 \% ; \mathrm{Si}=6.95 \% \mathrm{Mg}=0.25 \% ; \mathrm{Sr}=0.13 \% ; \mathrm{Zn}=$ $0.0098 \% ; \mathrm{Cu}=0.004 \% ; \mathrm{Ti}=0.13 \%, \mathrm{Sn}=0.002, \mathrm{Ni}=$ $0.005 \%$. (Zalensas D L, 1998).

The chemical composition of Al-TiB master alloy, Ti3B1 type (European Standard EN 575-1995 Regristration No.), with chemical composition: $\mathrm{Ti}=3 ; \mathrm{Si}=0.30 ; \mathrm{Fe}=0.35 ; \mathrm{B}$ $=1.0 ; \mathrm{V}=0.2$ the remainder is Al. (Zalensas D L, 1998).

The research procedure starts from the foundry to make alloys of the Al-7Si base material with the composition of the varied Ti: 0.13 (base material), $0.14 ; 0.15$ to $0.22 \mathrm{w} \%$. Furthermore, the alloy is given $\mathrm{T} 5$ heat treatment.

For implementation in the T5 heat treatment field can be carried out in the following manner: The alloy of the foundry is lowered to $530^{\circ} \mathrm{C}$, then cooled rapidly 
International Conference on Engineering, Advance Science and Industrial Application (ICETESIA) 2018

September 6-7 2018, Institut Teknologi Sepuluh Nopember, Surabaya, Indonesia

(quenching) to a temperature of $70^{\circ} \mathrm{C}$, the next step is the artificial aging process with the steps as follows :

Spesimen diangkat dari bak quenching, lalu dimasukkan ke dalam dapur-kecil untuk dilakukan proses artificial aging.

1. The initial temperature of the heating is $70^{\circ} \mathrm{C}$, this is adjusted to the temperature of the quenching medium

2. Temperature is raised to $154^{\circ} \mathrm{C}$, and the time required to achieve this is about 15 minutes.

3. fter that held holding time at temperature $154^{\circ} \mathrm{C}$ for 4.5 hours.

4. The final step takes out the specimen from the small heating kitchen, then cools it with the air-conditioning medium.

5. After that hold holding time at temperature $154^{\circ} \mathrm{C}$ for 4.5 hours

After heat treatment T5 then the next step is testing the mechanical properties. UTS and elongation testing with JIS Z 2241 standard, Hardness testing with JIS Z 2244 and impact test with JIS Z 2242, and last is metallographic testing.

\section{RESULT AND ANALYSIS}

\section{A. Mechanical Testing Result}

Test Result Mechanical properties before the heat treatment (as cast) and after the heat treatment, T5 can be seen in Table 3. Based on the test results can be concluded that with the addition of $\mathrm{TiB}$, then there is an improvement in mechanical properties, especially on tensile strength and hardness, but no one meets JIS H5202 standard. After T5 heat treatment occurs again the repair of mechanical properties to meet the requirements of JIS H5202 standard. ie on Al-7Si alloys with Titanium content: $0.13 \%$; $0.14 \%$; $0.15 \% ; 0.16 \% ; 0.17 \%$ and $0.18 \%$. However, the most optimum is Al-7Si alloy whose titanium content is $0.18 \%$ w.

The tensile test results show that the greater $\mathrm{Ti}$ content in both as-cast and treatment conditions, the UTS value will rise to $\mathrm{Ti}$ content of $0.18 \%$ (Figure 2), this is due to the greater $\mathrm{Ti}$ content the grain will be smoother), as shown in Figure 6, the microstructural photo.The smoother the grain, the UTS value will rise, because the dissemination of the dislocation is more difficult so that it has greater resistance, so to break the required greater energy, which means that UTS is getting bigger. When Ti content is increased again to $0.21 \%$, it no longer adds to the fine grain, but weakens the bonds between atoms, because the place where the excess $\mathrm{Ti}$ becomes the weak point of the dislocation occurs.Under the heat treated condition T5 always obtained a higher UTS value than the ac-cast condition, this is because after being given a T5 heat treatment the grain shape will become more rounded (Figure 7).

An increasingly round shape has greater resistance to propagation of dislocations so that to break it requires greater energy, this means that the UTS value is large.

The elongation test results (Fig. 3) showed different results with tensile test results. In the as-cast condition the greater the $\mathrm{Ti}$ content the elongation will decrease as the greater $\mathrm{Ti}$ content becomes smoother, so when given the deformation, the material is not easily elongated, this causes the elongation value to fall.

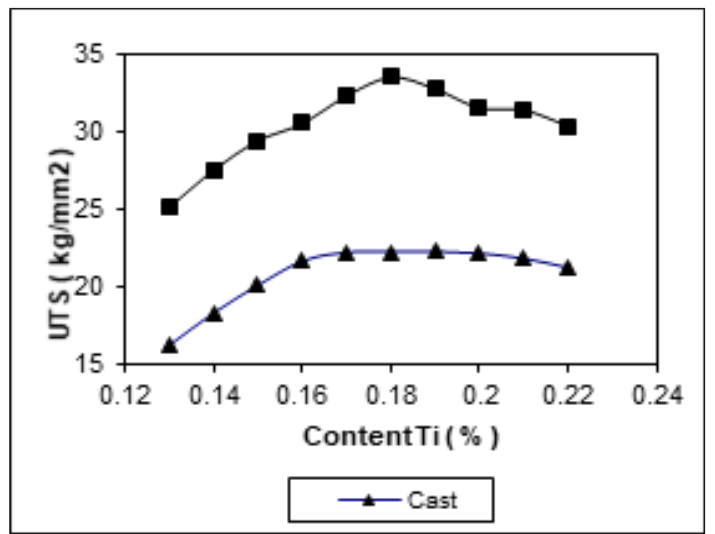

Figure 2. The relationship between Ti and T5 content against UTS on Al$7 \mathrm{Si}$.

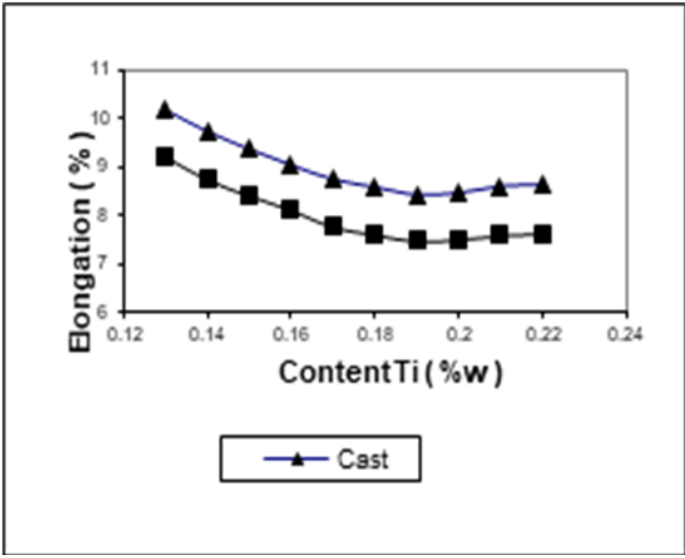

Figure 3. The relationship between $\mathrm{Ti}$ and $\mathrm{T} 5$ content to Elongation on $\mathrm{Al}-$ $7 \mathrm{Si}$.

Hardness test results show that the greater $\mathrm{Ti}$ content either as-cast condition or hardness treatment conditions will rise to Ti content of $0.19 \%$ (Figure 4) this is due to the greater Ti content the grains will be smoother as shown in Figure 6.

The smoother the grain, the hardness will increase, because in the fine grains have greater deformation resistance. Similarly, when the grain shape is more rounded, hardness also increases. This is why the hardness value in the T5 heat treatment condition is greater than the as-cast condition.

When the Ti content is increased again to $0.21 \% \mathrm{w}$ the hardness value becomes decreased, it turns out there is an excess of $\mathrm{Ti}$, where the excess $\mathrm{Ti}$ occurs where the weakness occurs dislocation, which means the force required to deform it to be small physically indicated by the decrease in hardness value. When associated with the value of UTS, then there is a match between UTS with hardness. The greater the value of UTS then in general, hardness value is also greater, so also if the opposite 
The results of the IS test (Figure 5) show that the greater the Ti content, the IS will fall in both the as-cast and heat treatment conditions. This is due to the smaller grains, the material will be weaker to withstand the impact of the shock (impact), in other words the material will become more brittle. Similarly, the more rounded the grain shape then the material will also be more brittle, this is causing the decline in the value of IS.

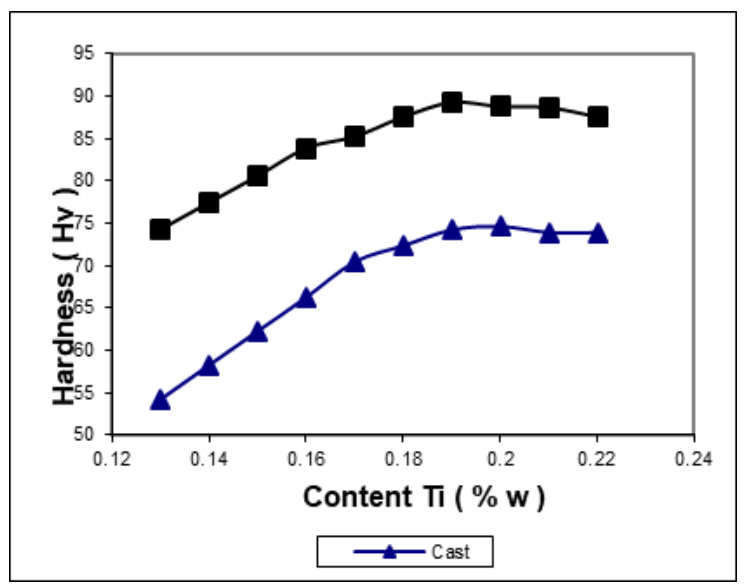

Figure 4. The relationship between Ti and T5 against hardness on Al-7Si.

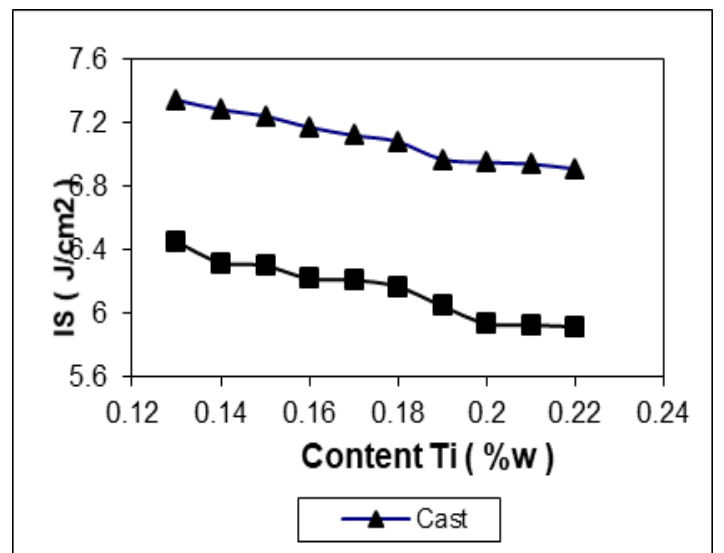

Figure 5. The relationship between Ti and T5 content against IS at Al-7Si.

\section{B. Results of Micro Photo Testing}

In the as-cast condition, the result of micro photo test shows that the greater the Ti content then the granular shape will be smaller (smooth). Figure 6a shows the granular form of $\mathrm{Al}-7 \mathrm{Si}$ base alloy (Ti content is $0.13 \% \mathrm{w}$ ). Then, after the $\mathrm{Ti}$ content is raised to $0.14 \% \mathrm{w}$ the granular shape will be subtly as shown by Figure $6 \mathrm{~b}$.

Next the Ti content is raised again to $0.15 ; 0.16 ; 0.17$; $0.18 ; 0.19 ; 0,20$ and $0,21 \%$ w. Microstructure results show that the form of the bitumen will be smoother (up to Ti content of $0,20 \% \mathrm{w}$ ), after the Ti content is above $0,20 \% \mathrm{w}$ its granular shape is not as smooth as shown by Figure $6 \mathrm{~h}$ and Figure 6i.

The granular form of granules is due to the fact that TiB can be the nucleus of the aluminum alloy during the freezing process. This is in line with TiB's function as a grain refiner on aluminum alloys

The addition of TiB can cause granules to be more subtle, whereas $\mathrm{T} 5$ heat treatment may cause granular changes. In the condition of as-cast the grain shape is oval, after heat treatment of the grain form becomes round as shown by Fig. 7 and Figure 8 . The change in the shape of the grain is the cause of the change in mechanical properties as described above.

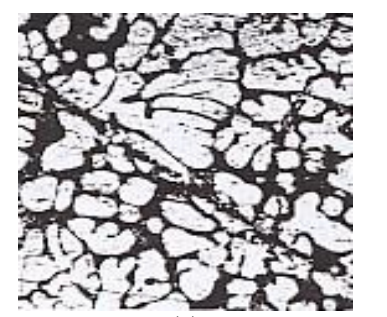

(a)

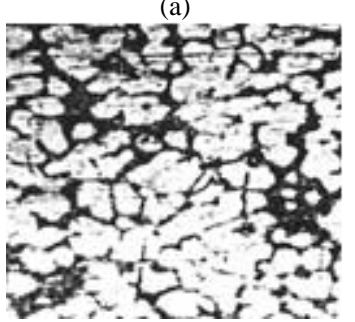

(c)
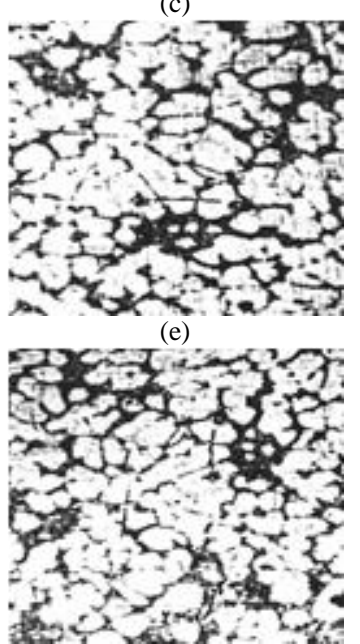

(g)

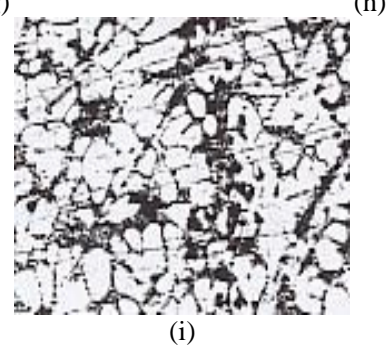

(h)

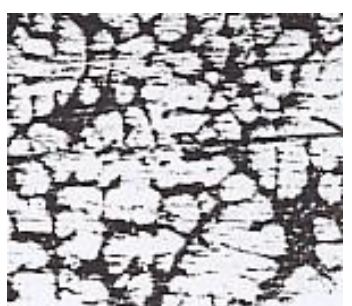

(b)
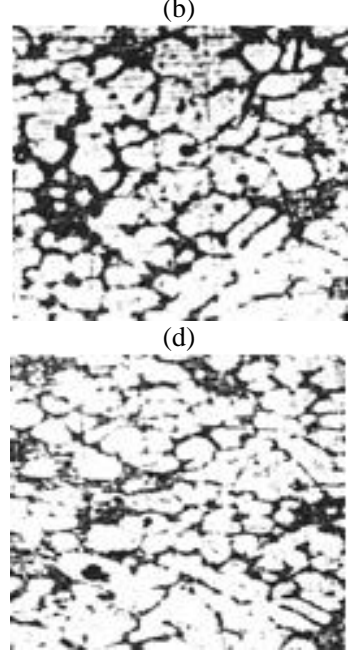

(f)

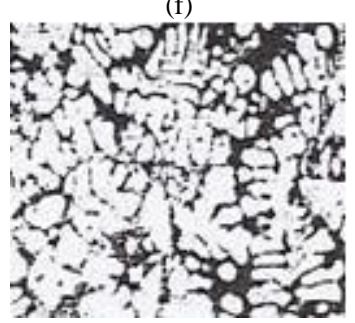

(i)

Figure 6. The microstructure photo of Al-7Si as-cast (enlargement of 200
a. $0,13 \% \mathrm{w}$
d. $0,16 \% \mathrm{w}$
b. $0,14 \% \mathrm{w}$
e. $0,17 \% \mathrm{w}$
c. $0,15 \% \mathrm{w}$.
g. $0,19 \% \mathrm{w}$
h. $0,20 \% \mathrm{w}$
f. $0,18 \% \mathrm{w}$
i. $0,21 \% \mathrm{w}$.

$\mathrm{x})$, Ti content of: 
International Conference on Engineering, Advance Science and Industrial Application (ICETESIA) 2018 September 6-7 2018, Institut Teknologi Sepuluh Nopember, Surabaya, Indonesia

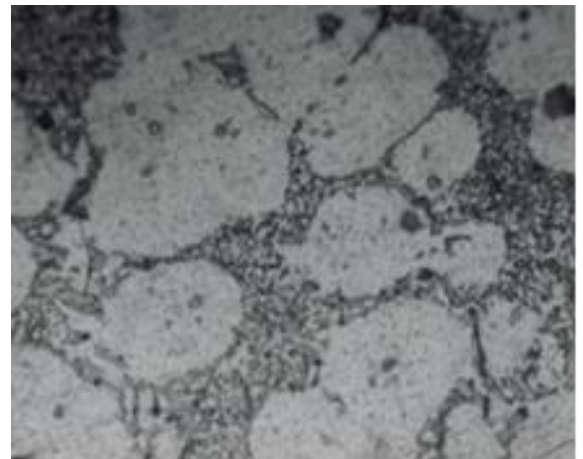

Figure 7. Photo of microstructure $\mathrm{Al}-7 \mathrm{Si}$, Ti content of 0.17 as-cast condition. (500 x Enlargement).

\section{CONCLUSION}

1. The addition of Al-TiB element to Al-Aluminum Al$7 \mathrm{Si}$ alloy can change the micro structure of the grains to be more subtle, thus changing the mechanical properties, increasing the UTS and hardness, but decreasing the elongation and IS, on the Ti content of $0.13 \mathrm{~s} / \mathrm{d} 0,18 \% \mathrm{w}$.

2. The heat treatment of $\mathrm{T} 5$ in Aluminum Al-7Si alloy can change the micro structure, the grain shape becomes more rounded, so that it can change the mechanical properties.

3. The mechanical properties of the as-cast conditions do not meet the JIS H5202 standard, although the Titanium content is increased.

4. The mechanical properties generated after heat treatment T5 can meet JIS H5202 standard, whose Titanium content is: $0.13 \mathrm{~s} / \mathrm{d} 0.18 \% \mathrm{w}$.

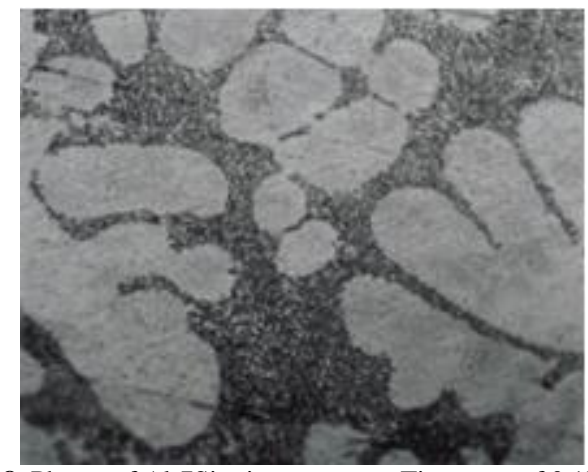

Figure 8. Photos of Al-7Si microstructure, Ti content of 0.17 T5 heat treatment conditions. (500x Enlargement).

5. The optimum Ti content is $0.18 \% \mathrm{w}$, which produces mechanical properties: UTS $=33.58 \mathrm{~kg} / \mathrm{mm} 2$, Elongation $8.14 \%$, Hardness $=93.74 \mathrm{HV}$ and $\mathrm{IS}=$ $5.92 \mathrm{~J} / \mathrm{cm} 2$

\section{REFERENCE}

[1] D. Zalensas, Aluminum Casting Technology, 2nd ed. American Foundrymen's, Inc, 1998.

[2] Suhariyanto, "Effect of $\mathrm{TiC}$ on mechanical properties and micro structure on Al-7Si alloy," in National Seminar of Mechanical Engineering, 2002.

[3] A. Samuel, "Effect of alloying element and DAS on the microstructure and hardnees of $\mathrm{Al}-\mathrm{Si}-\mathrm{Mg}$ aluminum die casting alloy," J. Math. Sci., vol. 30, pp. 1313-1319, 1998.

[4] E. H. John, "Aluminum, Properties and Physical Metallurgy," Ohio, 1994. 